Iain Borden

\title{
Skateboard City: London in Skateboarding Films
}

Pre-copy edited draft. Final version published in Pam Hirsch and Chris O'Rourke (eds.), London on Film: the City and Social Change, (London: Palgrave Macmillan, 2017 ).

In popular imagery, skateboarding is directly correlated with southern California surfing. Renowned documentaries like Dogtown and Z-Boys (Stacy Peralta, 2001) and Chlorine (Milan Spasic, 2003), plus Hollywood movies like Back to the Future (Robert Zemeckis, 1985), Gleaming the Cube (Graeme Clifford, 1989) and Lords of Dogtown (Catherine Hardwicke, 2005) all show blond-haired skateboarders riding against a backdrop of palm trees and clear blue skies.

Yet skateboarding is far from being entirely Californian. Even in the earliest days of the late 1950s and early 1960s, Florida and Australia were major skateboarding centres, along with cities in Britain, France, Germany and Brazil - and unsurprisingly London has long been part of this history. Important 1970s skateboard sites in the capital included public parks like Kensington Gardens and Crystal Palace, along with purpose-built skateparks such as Mad Dog Bowl (Old Kent Road), Meanwhile Gardens (Westbourne Park), Rolling Thunder (Brentford), Rom (Hornchurch), Skatecircus (Wandsworth Road), Skate City (Tooley Street), Solid Surf (Harrow) and Stockwell (Brixton), plus, since the 1990s, appropriated terrains like those around Shell Centre, Bishopsgate and St Paul's. And from the early 1970s onwards, the Southbank's "Undercroft" (beneath Queen Elizabeth Hall) has been another major location, sometimes referred to as UK skateboarding"s Garden of Eden. (Borden 2015)

This chapter charts London skateboarding as captured through different forms of moving image, disclosing a vibrant scene of national and international repute. In doing so, the chapter raises wider sub-themes, ranging from architectural design, historic preservation, cognitive mapping and public space to creative industries, social diversity, neoliberalism and globalisation. (Borden 2001) The chapter also registers changing technologies in skateboarding documentations, from television and conventional film-making to commercial videos, amateur camcorder projects and contemporary social media. 


\section{False Dawn}

In 1965 Londoner Roy Giles wrote to American magazine The Quarterly SkateBoarder to extol the virtues of UK skateboarding, centred on the capital and surfing centres like St. Ives in Cornwall and Langland Bay in South Wales. ("Skateboarding Around the World"; Over Plywood) The British public also learned about this new phenomenon from the national press, Popular Mechanics and Life, films like the Academy Award-nominated Skaterdater (Noel Black, 1965) and Canadian The Devil's Toy (Claude Jutra, 1966), or from British Pathé news features at local cinemas. (Pennell; Boykin and Grant; "Skateboard Mania"; "Gremlins and Sandies") Celebrities also joined in, and both singer Tom Jones and Conservative Party Leader Edward Heath were photographed skateboarding in London settings, with Heath's precarious attempts in Kensington's Camden House Terrace being captured by ITN. ("Tory Leader")

Despite this worldwide reach, the nascent skateboard bubble quickly burst. By the end of 1965, American skateboard manufacturers like Makaha suffered cancelled orders worth hundreds of thousands of dollars, and as Dick Metz of Hobie skateboards explained, "for two or three years you couldn't hardly give a skateboard away." (Marcus and Griggi, 55)

\section{Halcyon Days}

In the early to mid 1970s skateboarding boomed again. Fuelled by technological advancements in the form of polyurethane wheels, purposedesigned trucks and kicktail decks, and inspired by short-board surfing innovations, skateboarding took off dramatically; as Dogtown and $z$ Boys shows, Californian skaters rode up schoolyard banks and swimming pool walls, as well as concrete reservoirs, pipes and ditches. New magazines were launched (including the incredibly popular US SkateBoarder in 1975), purpose-built skateparks arose in New Zealand, Australia and USA, and enthusiastically received documentaries included the Australian Ultimate Flex Machine (Jason Cameron, 1975) and American Spinn'in Wheels (Chris Carmichael, 1975), Magic Rolling Board (Jim Freeman and Greg MacGillivray, 1976), Blaze On (Al Benner, 1978) and Skateboard Madness (Julian Pena, 1979). The BBC travelled to California for its "Skateboard Kings" documentary for "The World About Us" (1978), providing many London skaters with their first moving images of Tony Alva and other famous "Dogtown" (Venice Beach) skateboarders. 
British and London skateboarding was also being reborn. By 1975 American manufacturer Bahne was frantically fulfilling UK and worldwide orders, in 1976 UK retail was lead by London's Slick Willies American Store on Kensington High Street and Alpine sports on Brompton Road, while a year later the Britain's Morris Vulcan was producing 15,000 boards every week. (Marcus and Griggi, 55 and 120-3; Phillips, 2004, 69; Phillips, 2007), 1215; Snyder, 28-9, 34 and 43) London-based publications like Skateboard!, Skateboard Special and Skateboard News appeared, rapidly joined by competitions organized by the London Evening News (August 1977), the BBC's "Nationwide" programme (late 1977), and The Sun (May-September 1978), plus sundry coverage like several items on London Weekend Television's Saturday morning "Our Show" (1977-8), Meanwhile Gardens skaters in an episode of BBC's police series “Z Cars” (1977-8), London skater Simon Napper appearing on BBC's "Stopwatch" (June 1978), and Sebastian Witkin skateboarding around Wandsworth's Arndale Centre in Sweeney 2 (Tom Clegg, 1978). ("The Man Who Spotted the Skateboard Trend"; "Reports on the 1st National Championships"; "Lip Torque"; "The Sun British Skateboard Championships") . A four-day National Skateboard Show was held in February 1978 at the Royal Horticultural Halls, with elaborate displays from equipment manufacturers and skatepark constructors. ("National skateboard Show") The same year, Prince Charles was filmed visiting the community "Talacre" skatepark - part of the progressive Inter-Action social initiative on a Kentish Town bombsite besides Talacre Road and Prince of Wales Road - and even taking cautious rides in his heeled shoes, blazer and tie. ("HRH The Prince of Wales visit to Inter-Action")

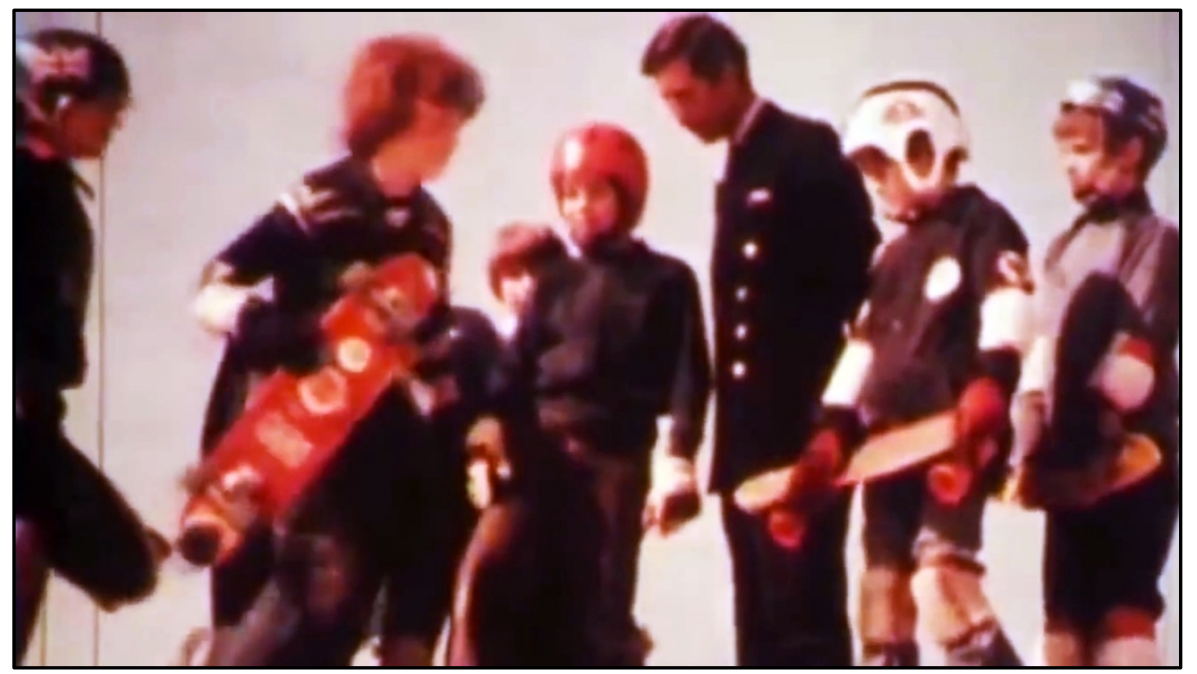

Prince Charles visiting Talacre skatepark, Kentish Town, (1978). https : //www $\cdot$ youtube.com/watch?v=fFbyszGSfng 
That London was now a major skateboarding centre is nowhere more evident than in Richard Gayer's Hot Wheels 'n' Big Deals (1978). Supporting box office hit Grease, Hot Wheels (as the film is commonly known) was seen by hundreds of thousands of UK movie-goers. To begin with, the 20 minute documentary shows skateboarding in Trafalgar Square, Covent Garden, Portobello Road, Undercroft, Crystal Palace and Hyde Park, along with a demonstration by US Hobie team riders and others at Islington's Michael Sobell Centre. Where Hot Wheels really triumphs is in its treatment of the Meanwhile Gardens community-based skatepark and, in particular, of the much more grandiose skate City commercial facility. Although lasting barely a year - built by Skate Park Construction on a Thames-side Tooley Street site, Skate City opened in August 1977 and closed just 14 months later this open air skatepark famously provided the country's first truly vertical bowls. Hot Wheels duly shows the likes of Simon Napper, John Sablosky, Jeremy Henderson, Alex Turnbull, John Turnbull, Paul Sully and Hugo Carey carving around steeply transitioned walls, performing kickturns and tailblock moves, and even shooting aerial manoeuvres out of skate City's notorious Black Bowl. (Skate Park Construction; “The Sun Rises on Skate City", "UK News"; Brown de Colstoun; Rollin' through the Decades).

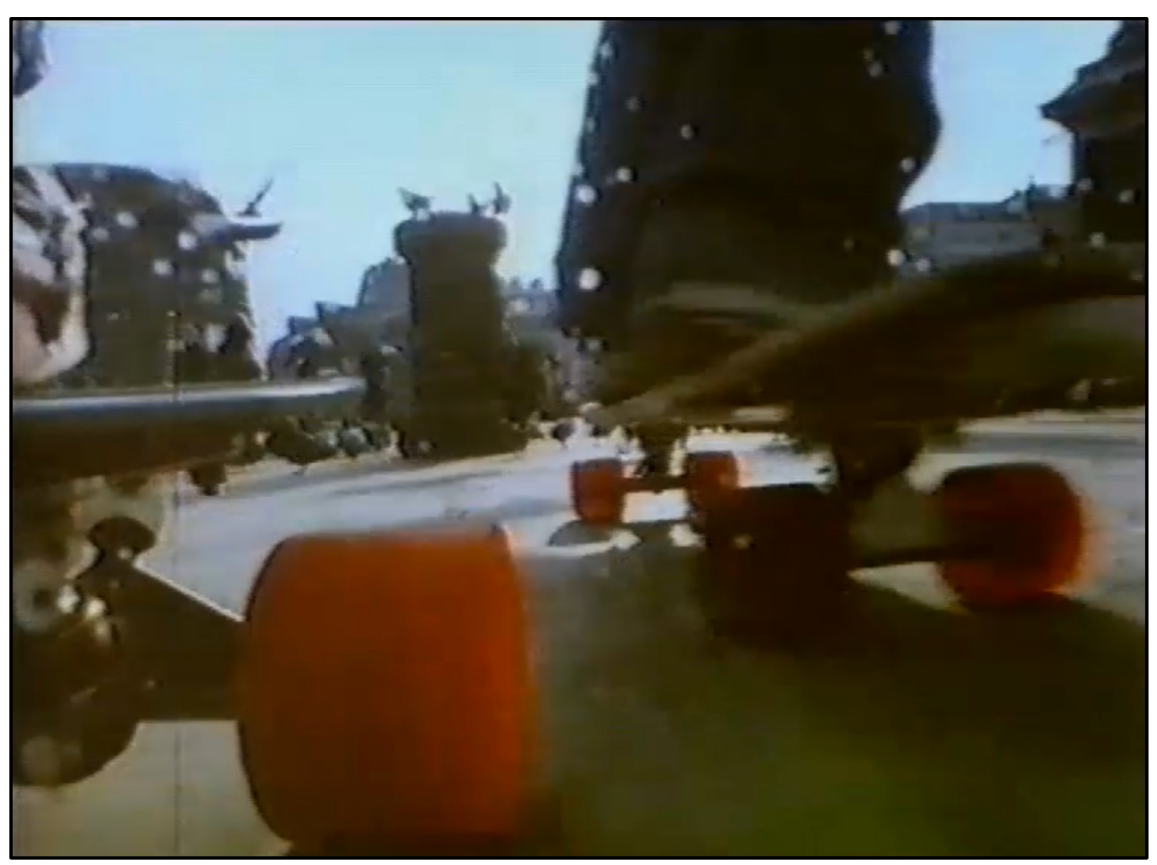

Skateboarding in Trafalgar Square, shot using a skateboard-mounted camera viewing via a $45^{\circ}$ angled mirror. Hot Wheels (Richard Gayer, 1978). https : //WwW -youtube.com/watch? v=HlCtGQZrTzk 
On one level, Hot Wheels is important for providing extensive footage of London's original skatepark. Some amateur and news snippets of Skate City also survive, as do clips of other London skateparks, such as the Mad Dog Bowl in a disused cinema on old Kent Road and Rolling Thunder within the abandoned Brentford Market. ("United States Skateboarding Aces"; "Skate Boarding: Skate City"; "Skate City"; "Team of Youngsters"; "Vintage Footage of Rolling Thunder") A short news item on Hillingdon's tent-covered Spandrel Skate Dome includes Logos team riders Shane Cutts, Alex Turnbull and Ben Liddell, along with visiting American professional Bobby Piercy. ("Young Skateboard Fans"; Liddell) Even better are sequences shot at Harrow's Solid Surf, notably a promotional short for UK skateboard manufacturer Benjyboards (owned by actor Ben Howard and Pretty Things keyboardist John Povey) in which the likes of Jeremy Henderson, John Sablosky, Marc Sinclair and Jules Gayton ride the skatepark's half-pipe, pool and intimidatingly large "Performance Bowl." ("Benjyboard promo video"; "John Sablosky.avi"; "Jeremy Henderson $02 . a v i "$; "Marc Sinclair.avi"; "Jules Gayton.avi"; "Baker Skates"; Rollin" through the Decades) Nonetheless, Hot Wheels remains the best recording of London skatepark-riding, providing invaluable documentation of a unique episode in the capital's architectural and social history.

Besides providing historical evidence, how Hot wheels records skateboarding is just as significant, presenting London as a montage of places, bodies and moves; the Skate City sequences, for example, are intercut with footage from Meanwhile Gardens and the Michael Sobell Centre demo, while sophisticated filming and editing techniques - including slowmotion, blurs, fast-pans, skateboard-mounted cameras viewing via angled mirrors, and closely-miked roaring wheels - further destabilise the skatepark as a rational entity. Rather than being presented as an identifiable site and named individuals, in Hot Wheels skate City becomes a glorious mélange of place, people and action, and of different views, sounds and speeds. This effect is further heightened by the inclusion of many black, female and older skaters alongside more stereotypical white male teenagers. In this seductively sweet yet subtly sophisticated portrayal of skateboarding's halcyon days - as yet seemingly untroubled by commercial pressures, cultural constraints or legal restrictions - London is a truly joyous world, where all kinds of people create their own city from vital energy, simple technology and inventive architecture. And Hot Wheels suggests that film is the best way to represent this activity, 
capturing skateboarding's vivacity in a manner far more dynamic than could any text or photograph.

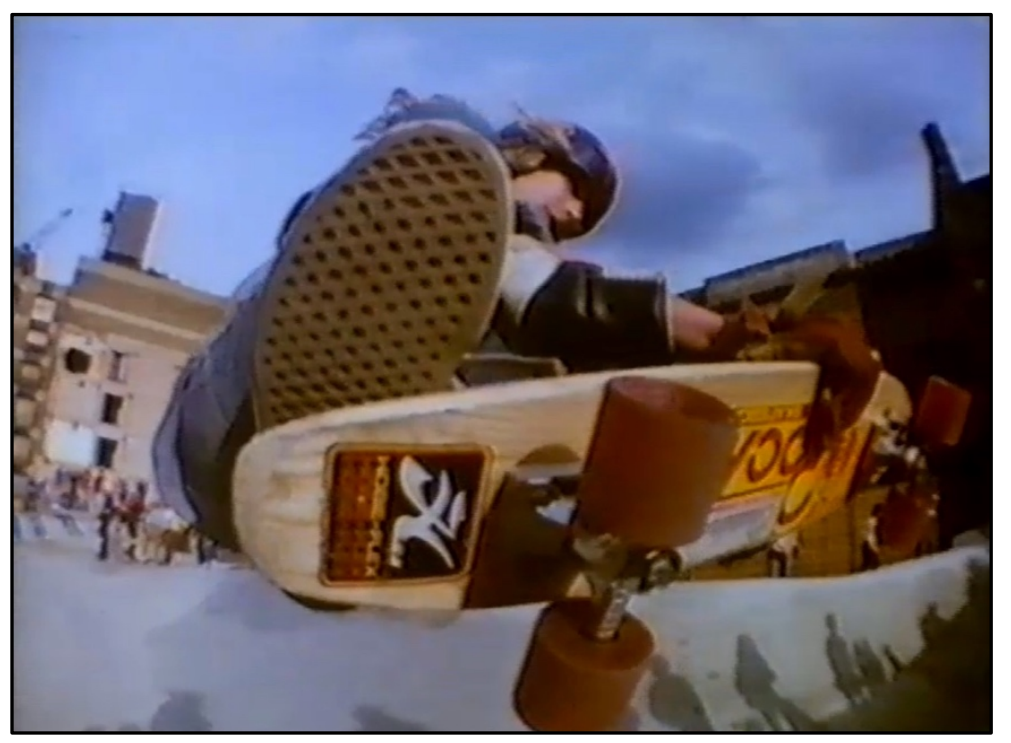

John Sablosky performing a frontside aerial at Skate City's "Black Bowl". Slow motion sequence from Hot Wheels (Richard Gayer, 1978). https: //www $\cdot$ youtube.com/watch?v=Gyl1AceKBLc

\section{Renaissance}

Yet, however vibrant might be Hot wheels and other 1970s depictions of skateboarding, they are clearly created not by integral protagonists but by filmers and journalists who, although sympathetic to skateboarding's youthful energy and spatial innovation, remained as somewhat distanced observers.

This all soon changed. During a dramatic downturn in popularity during the early-mid 1980s, a few skaters struggled on at the Undercroft plus a few other London locations like the Crystal Palace, Crouch End and Westway half-pipes (stand-alone U-shaped constructions measuring 3-4m tall), these isolated scenes being captured by the skaters themselves in rare documentaries like Graham Fletcher-Cook's Ollie the Gap (1988) and Winstan Whitter's retrospective Rollin' through the Decades (2005).

Yet not all was lost. Fuelled by skateboarding's rebirth as a predominantly street-based activity - in contrast to the mainly skatepark and half-pipe settings of the 1970s and early/mid 1980s - UK skateboarding enjoyed a massive renaissance from the late 1980s onwards, and with the capital at its very heart. London-centric videos like Deathbox's Spirit of the Blitz (Dave Evans, 1991), Panic and Blueprint's Anthems (Alvin Singfield, 1997) and the independently-released Playing Fields (Franklin 
Stephens, Mark Channer, Mat Fowler, Ben Rodriguez and Ben Powell, 1997) are a form of cinema verité, where skaters traverse actual streets, confront security guards, get ejected from skate spots and slam hard, the overall sense of uproarious behaviour being enhanced by the videos' authentically blurry, shaky and grainy quality. Gone now were the semi-official 1970s recordings of skateboarding as a predominantly American import and innocent activity, as promulgated by broadcasters like the BBC and expert filmmakers like Gayer, being replaced by self-made productions emanating from skateboarders themselves, and exemplified by camcorder usage, miniscule budgets, low production quality and rough editing, and yet somehow instilled with a raucous mood and indefatigable energy. (Griffin) As artist Nam June Paik described the liberatory potential of the new camcorder technology, “Television has been attacking us all our lives. Now we can attack it back." (Elwes)

These skater-directed camcorder productions, alongside other new technologies, also led to skateboarding being relayed much more rapidly, so generating innovative tricks. "News of modern moves, the tricky tricks and the flippity kicks," reported Thrasher in 1991, "spread like wildfire via phone, fax, Xerox and mini-cams." ("Major Moves") Indeed, print-based skateboard magazines like the American Thrasher and the London-based R.A.D. ("Read And Destroy") and Sidewalk Surfer resorted to repurposing VHS and Hi-8 footage into grainy multi-frame sequences which captured complex street tricks. Furthermore, in the videos themselves, the use of close-up views, ultra-fish-eye lenses and hand-held cameras, along with the common inclusion in shot of skater-filmers alongside skater-riders (either directly or indirectly through obvious shadows and filming equipment), all reinforces the sense that filmers, performers and viewers alike are part of the same community, equally integral to skateboarding's fast-paced invasion of the city core. As pro rider Matt Hensley noted of these skater-made videos, "kids everywhere saw that and said, yes, we can do this." ("Matt Hensley on Skateboarding")

On one level these videos, as with Hot Wheels, provide a useful guide to significant London skatespots and skaters. For example, in Anthems, Matt Pritchard flies down 13 steps at Bishopsgate and jumps a $3.5 \mathrm{~m}$ gap across "Bird Shit Banks" at the Southbank, Colin Kennedy grinds an Undercroft wall ledge and slides along City handrails, John Rattray negotiates flat ground and walls besides St Paul's, and Paul Shier performs ollies and flips at the Shell Centre, while in Playing Fields Alex Moul, Colin Kennedy, Mat 
Fowler and Frank Stephens undertake similar actions at the Barbican, Broadgate and Royal College of Physicians, while also falling down staircases, thumping off walls and dicing with traffic. And in the youthoriented television programme "RAD," broadcast between 1998-2003, skater Marc Churchill provides an alternative tourist guide, featuring famous skateboarding places like Euston Station banks, Victoria street benches, Bishopsgate ledges, Stockwell skatepark, Kennington Park bowl, and Meanwhile II skatepark's “Gonz gap." (“RAD - London's Skate Spots"; “RAD a Look at London's Skateparks")

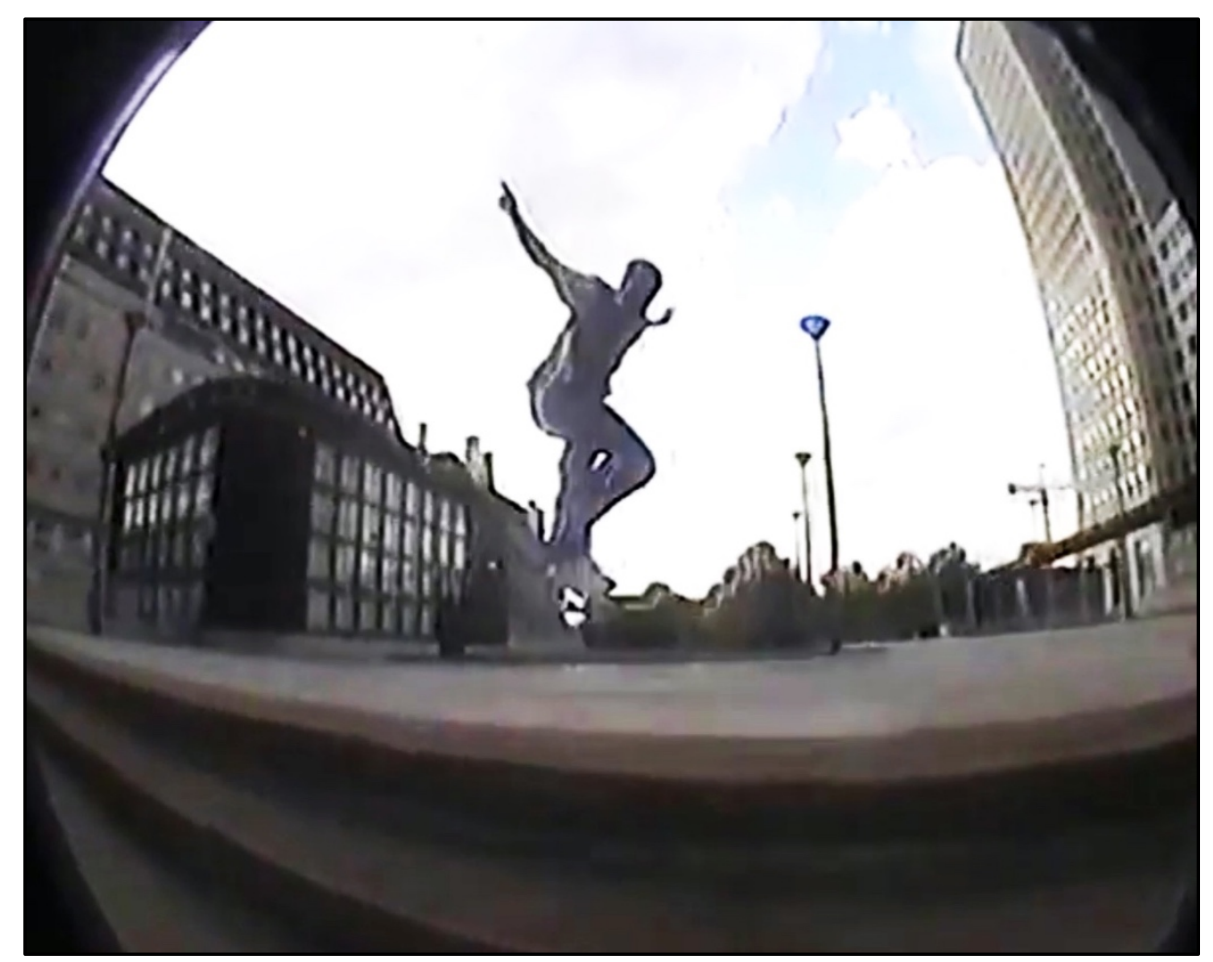

Paul Shier captured by ultra-fish-eye lensed camcorder at the Shell Centre. Panic and Blueprint's Anthems (Alvin Singfield, 1997). https : / /www.youtube.com/watch?v=jQbrzCSR64U

More than just recordings of London skateboarding sites, however, these 1990s videos helped mount significant critiques of urban space and architecture. The tendency discernible in Hot wheels to prioritise personal experience over rational visualisations of London now became a dominant trope, with the mobile skater-held cameras and fish-eye lenses (often held right down at ankle-level) emphasising the rushing skater and their immediate terrain over any sense of recognisable monuments or other conventional representations. The normative architecture of London, conventionally thought of as whole buildings, named designers and clearly mapped listings, is consequently fractured by these skate videos into a 
series of discontinuous ledges, steps, walls and banks, before being recomposed into a new unity through the editing together of skateboarders' multiple runs through the city, and further consolidated by accompanying rock, reggae or dance tracks. At its most extreme, in a video like Death Squad, the Movie (1998) by the UK's Death outfit, London skateboarding architecture is almost entirely splintered within an anarchic assemblage of British skateparks, street spots, skaters and everyday scenes.

Alternatively, as later recalled in Rollin' through the Decades, a notorious skatepark like The Arches, a short-lived 1991 insertion in Ewer Street near London Bridge, emerges as a half-hidden event-space in which hurriedly constructed ramps, left-over theatrical props, dodgy financing, sketchy admissions and a carnivalesque atmosphere combined into an intense skateboarding crucible. As Curtis McCann declared, The Arches was “buzzing, like a video-shoot every day," the archetypal London skate venue "where people should be pushing stuff, and people should be going off." Here London is revealed as being constructed not just from official sites or landmarks, but also from semi-secret hideaways, accessible only to those in-the-know and with the requisite determination to seek them out.

With such videos, therefore, comes a significant critique of London urbanism, suggesting that the city exists not just for work and leisure, business people and shoppers, prescribed and reliable functions, but also for acts of pure pleasure, people of all ages and appearance, and for risky and transgressive behaviours. London architecture, it is so declared, is not only designed by architects, laid out by planners, controlled by urban managers and described by official guides, but becomes a true social space when ordinary Londoners re-use it as part of their everyday lives, and often in unusual, unpredictable and uncontrolled manners.

\section{Within and Beyond London}

The dual process of documenting and critiquing unsurprisingly continues into the 2000s and 2010s, with notable videos and documentaries like In Motion (Neil Chester and Ben Powell, 2003), OG Distribution's Never Been Loved (Kevin Parrott, 2005), Rollin' through the Decades (Winstan Whitter, 2005), Blueprint's Lost and Found (Dan Magee, 2005) and Make Friends with the Colour Blue (Dan Magee, 2010), Death Skateboards' Better Than Life (2008), Heel Toe Magic (Andy Evans, 2009), Square One (Jacob Harris, 2009), The Lovenskate Video (Samuel Smith, 2012), Eleventh Hour (Jacob Harris, 2013), Skate World: England (Vice, 2013), Heroin Skateboards' Video Nasty 
(2013), Albion (Kevin Parrott, Morph and Ryan Gray, 2014), Rugged Raw (Jake Martinelli, 2014) and Isle's Vase (Jacob Harris, 2015). And in overall approach, these productions are not remarkably different to their 1990s precursors, although they do update the ever-changing rota of riders and skatespots; as Skate London (Josh Stewart, 2014) shows, these might include the likes of Tom Knox and Nick Jensen skating a ledge besides Blackfriars Bridge or an open yard in Borough. "There are so many different quirks and avenues and alleyways you can take off and make your own path," comments Jensen. "That's the beauty of London, it's spontaneous and always new things are coming up."

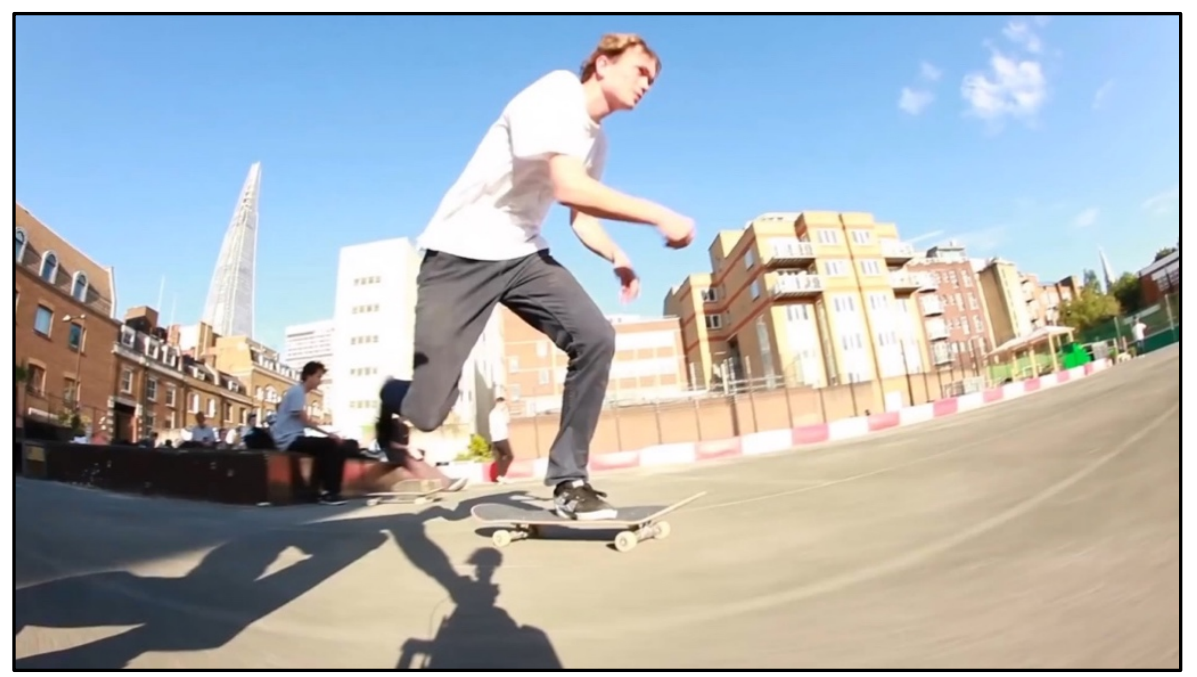

Nick Jensen skateboarding an open yard in Borough. Skate London (Josh Stewart, 2014). Note the shadow of the close-tracking skater-filmer. https : //www . youtube.com/watch?v=uFcNTUNT9SI

Besides the continual documentation of street spots, riders and skateboarding's performative critique of public space, several films have amplified London skateboarding in other significant ways, on the one hand exploring the richness of the immediate scene, and on the other hand charting its impact upon a wider geography. In this way they extend our understanding of skateboarding both deeper within and extending far beyond the capital.

Notable here is the increasing politicisation of skateboarding as resistant to neo-liberalism, now moving from skateboarding's inherent 1990s performative critique of consumerism and business culture into more outright confrontations. In London this most clearly occurred in the concerted skateboarder-led campaign under the Long Live Southbank (LLSB) banner to prevent skateboarding and associated BMX and graffiti activities from being moved from the Undercroft to another nearby location - a long- 
threatened development which was finally proposed officially by the Southbank Centre in 2013. (Borden, 2014, 2015) This is not the place to explicate these events, but suffice to note that film was crucial in generating support for the ultimately successful campaign. For example, documentaries like Save South Bank (Winstan Whitter, 2008), The Bigger Picture (LLSB, 2013), You Can't Move History (LLSB, 2015) and The Undercroft (Jonathan Caicedo-Galindo, 2015) variously mounted critiques of alternative proposals, strengthened historical understanding, and celebrated the diversity of Undercroft users. In particular, LLSB cleverly amalgamated its films with physical (on-site presence, marches etc.) and digital (online petitions, website, social media etc.) activities - a strategy which later won "engagement campaign of the year" from the change Opinion Awards.

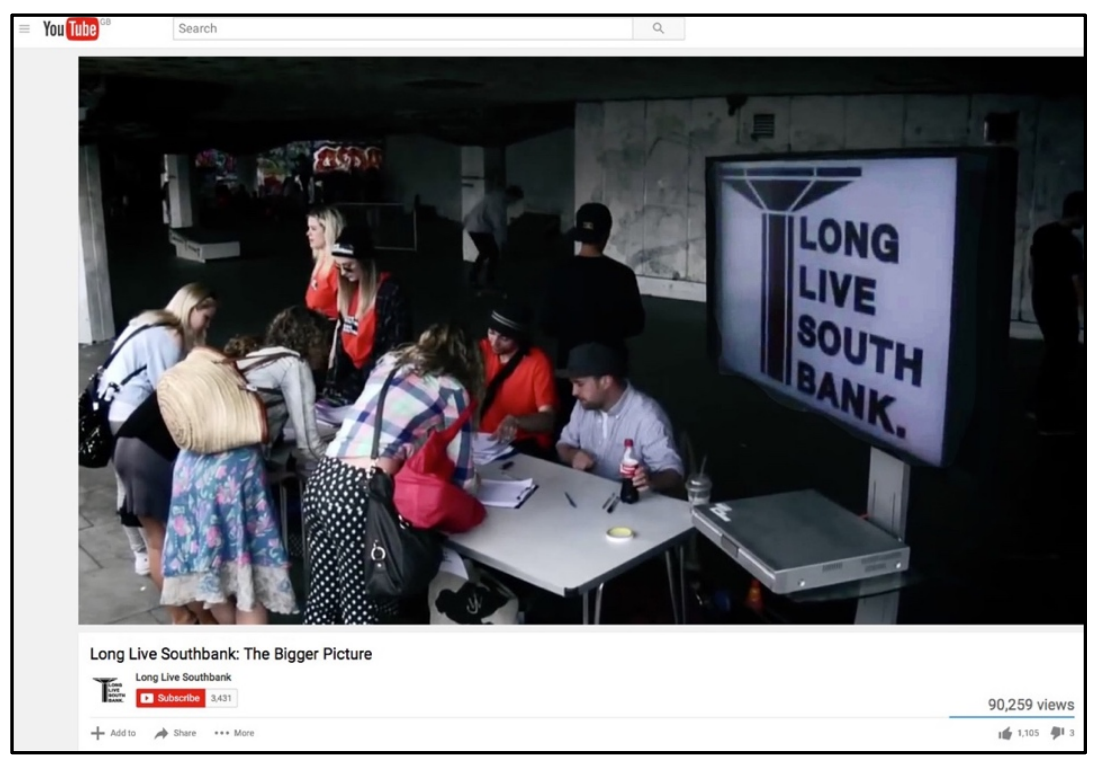

Long Live Southbank's campaign table at the Undercroft, as shown in The Bigger Picture (LLSB, 2013 ) and disseminated via YouTube. https : //www . youtube.com/watch? v=iFakN98Xg3E

The Undercroft campaign's success also benefitted greatly from a general and growing realisation that skateboarding is closely coupled with other artistic activities, from painting, film-making, photography and street art to dance, music and poetry. This is clearly evident in numerous video shorts making direct connections between London skateboarding and creative industries, such as Philip Evans' YouTube interview with skaterartist Nick Jensen. (Evans, 2010) It is even more dramatically demonstrated in the work of someone like Angus Leadley Brown, who in the early 2000s produced a series of time-lapse "synchroballistic" photographs (where the 
film stock is motorised across an open lens) disclosing skaters' moves as distorted continuums of body and skateboard. Extending this technique into moving images, Leadley Brown's video Passenger (2004) tracks Greg Finch skateboarding across High Holborn and Queen Victoria Street towards London Bridge, intercut with extraordinary sequences in which skater and board writhe and distend, as other-worldly contortions of body, space and time. More subtly, Philip Evans' London with Nick Jensen (2013) instalment of The Panoramic Series of videos deploys an ultra-wide aspect ratio to artfully shift attention away from the skateboarder, instead heightening the viewer's awareness of adjacent spaces, figures and rhythms in the broader cityscape. Similarly Tim Kellner's short London Night Skate (2014) extends temporal and perceptual boundaries, exploring skateboarding in the capital's darkened streets, now rendered dream-like by artificial light, slower speeds and inky shadows.

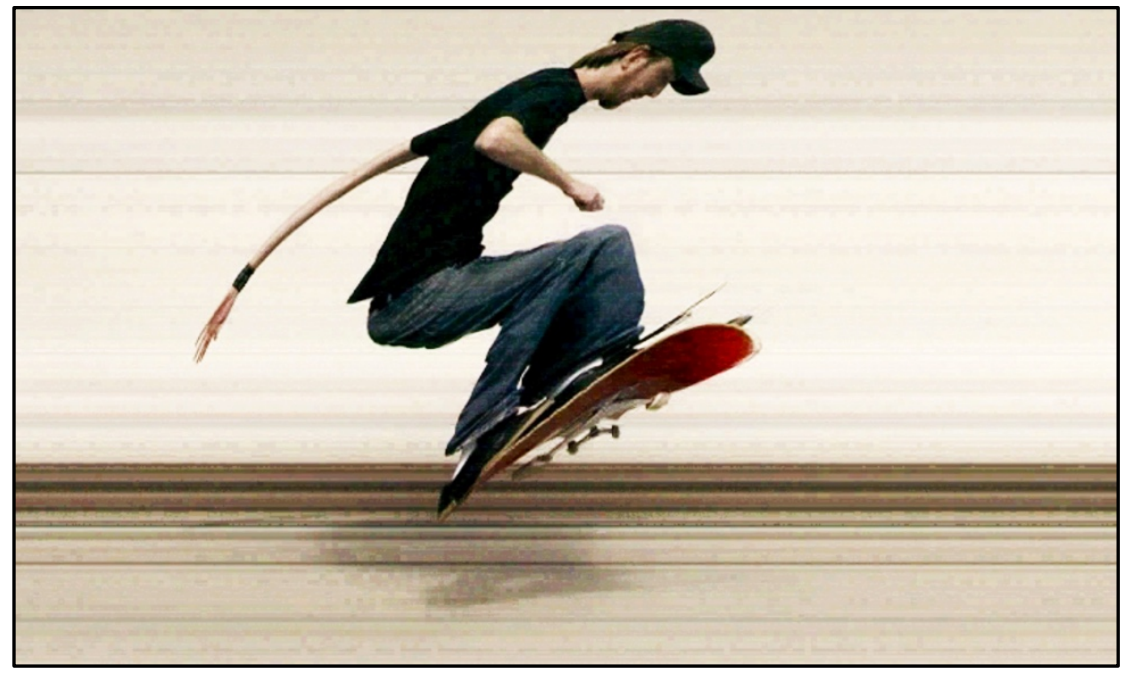

Greg Finch captured in Angus Leadley Brown's synchroballistic Passenger (2004). https://vimeo.com/103470163

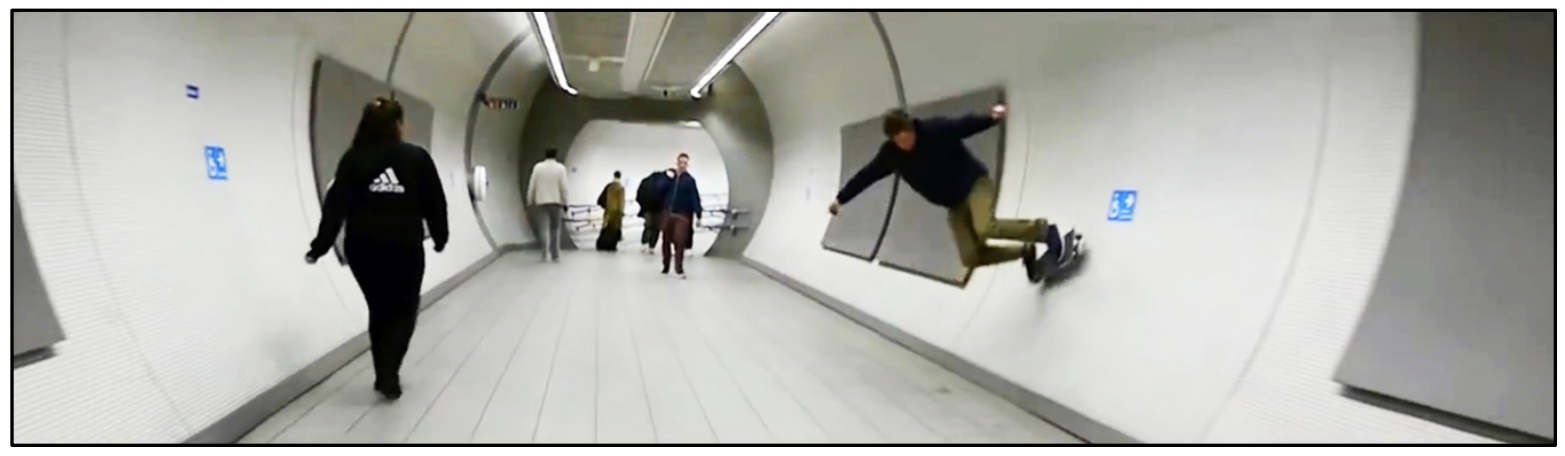

8 Down in the London Tube, with Nick Jensen skateboarding. The Panoramic Series (Philip Evans, 2013). https://vimeo.com/67379316 
As these videos suggest, filmic representations of urban skateboarding are often different to conventional A-B journeys made using A-Z guides, being closer to Situationist tactics of the dérive, détournement and psychogeography, and undertaken through drifting journeys and emotionallyinformed cognitive maps. Quentin Stevens, Kim Dovey and Hunter Fine have even related such skateboarding trajectories to Deleuze and Guattari's "rhizome" concept, by which non-organisational connections are made between multiple and non-hierarchical points. "We observe the cracks and the curbs, the absurdity that our city has an unadmired beauty," states skateboarding video poem A Guide to Cracks \& Curbs: London (Shade Media and Mat Lloyd, 2015). "Our commute is from A to everywhere, it is your nothing and our everything."

In a slightly different manner, documentaries like Format Perspective (Philip Evans, 2012) track the creative aspects of skateboard photography, including the work of London-based lensman Alex Irvine, who records skateparks like Stockwell and Tottenham Hale alongside other locations worldwide. TransWorld Skateboarding's documentary The Cinematographer Project (2012) similarly incorporates film-maker Torsten Frank, who charts skaters like Chewy Cannon in a high-speed traverse of London pavements, steps, underpasses, roads and car parks.

Alongside skater-artists, skater-filmers and skater-poets, skateboarding in London, as elsewhere, is increasingly being practised by a richer demographic. Hence Lucia Helenka's The Fat: Facts About Skateboarding (2001) inspects the mind-set and social diversity of London skaters, while in 2014 BBC London News reported amazedly on the increasing appearance of skaters in their $30 \mathrm{~s}$ and older, including a school chaplain. ("BBC London News Features Skateboarding") Two documentaries by Jenna Selby, As If and What? (2009) and Days Like These (2015), similarly celebrate the rising numbers of female skaters, showing the likes of Lucy Adams, Lacey Baker, Charlotte Brennan, Sam Bruce, Laura Goh, Savannah Keenan, Helena Long, Camilla Mullins, Lois Pendlebury, Emma Richardson and Zoe Kings riding at innumerable London skateparks and street spots. 


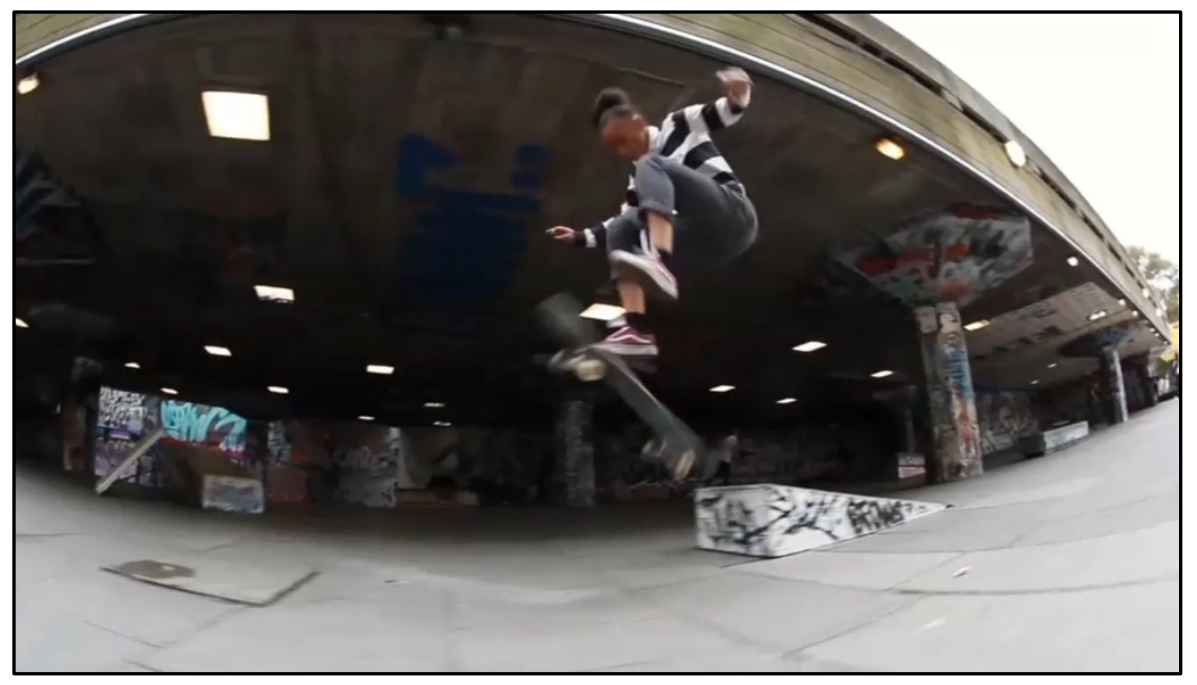

Savannah Keenan at the Undercroft. Days Like These (Jenna Selby, 2015). https : //dayslikethesefilm.uk

The growing interest in skateboarding is also resulting in explorations of particular skateparks and wider histories. When in October 2014 Rom in Hornchurch, at the eastern end of London's District Line, became only the second skatepark worldwide to achieve historic preservation status, the international media coverage included extensive BBC and ITN news reporting. (BBC1 News; ITN) Subsequently, a major documentary is being prepared; directed by Matt Harris, Rom Boys: 40 Years of Rad, will be released in 2018 to coincide with Rom skatepark's fortieth anniversary. Another documentary, A Concrete California (Jim Ford), on UK skateboarding is also in the early stages of preparation, in which London will inevitably feature strongly.

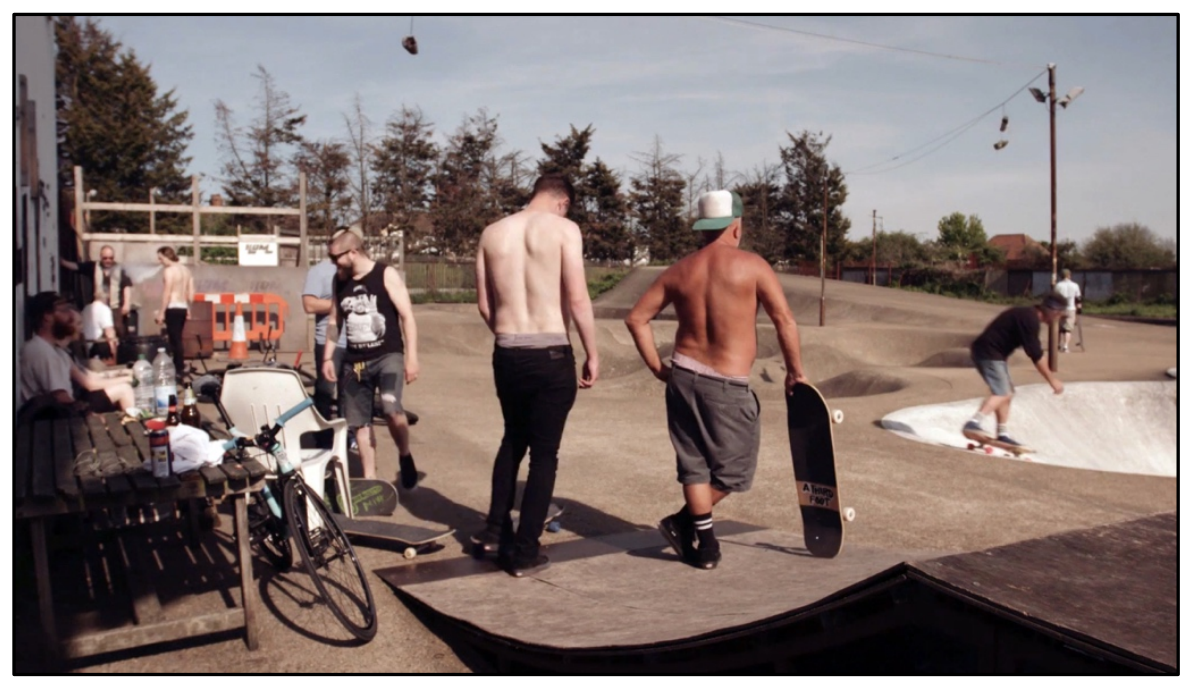

Rom skatepark, trailer for Rom Boys: 40 Years of Rad (Matt Harris, 2018). http: //romboys.film 
Yet if all these political, artistic, inclusionary and historicallyminded films present London skateboarding as a vital cultural phenomenon, then it must also be noted how skateboarding's espousal of independence, robustness and self-reliance chimes readily with neoliberalism's expectation that citizens should be autonomous, adaptable and selfreflexive. As historians Kara-Jane Lombard and Sean Dinces note, skateboarders, as entrepreneurs of their own skills and talents, are part of the general emergence of exactly this kind of neoliberal individual, integral to late capitalism's strategy of flexible accumulation.

In film, we see this in the trajectory of current London street skaters like Chewy Cannon, Benny Fairfax, Blondey McCoy and Caspar Brooker. These skaters were once marked as being "up from South London" and "up from the Undercroft" in various Henry Edwards-Wood videos, including City of Rats (2012) for London's renowned shop Slam City Skates and the "Hold Tight London" series "documenting and promoting the underground London skateboard scene." Edwards-Wood's 2011 promo for Stella supply in particular depicts such south London skaters as a roving band of beer drinkers and fighting dog-owners, who, to the tune of Buccaneer's ragga track "Fade Away," aggressively defy security guards and laugh-off unhappy local residents, and in a manner no doubt intended as authentically gritty. However, after featuring heavily in the rise of skateboarding-themed clothing/fashion Palace - a brand set up by Slam City's owners as the capital's rival to New York's uber-trendy Supreme - many of these skaters star in high budget marketing-centric skate videos like Adidas' Away Days (Matt Irving, 2016), hence helping this global sports brand (and occasional partner Palace) to promote shoes, clothing, footballs and other merchandise. Through such filmic journeys, street-level London kudos has been expertly leveraged into globalised marketing and fashion, while simultaneously shifting away skaters like Cannon, Fairfax and McCoy - who star in Away Days - from the anti-mainstream ethos of their earlier videos. "As representatives of Adidas Skateboarding and Palace," announces the blurb accompanying another promo video, "Chewy Cannon and Benny Fairfax exemplify the essence of London street skating and can be seen in this exclusive edit extending the classic London style to spots all over the globe." ("Adidas Skateboarding Benny \& Chewy Palace") Or as another Adidas/Palace video, this time centred on the Undercroft skate spot, concludes, “Run, skate, chill, go to the shop". ("Adidas Originals | Palace Skateboards") 


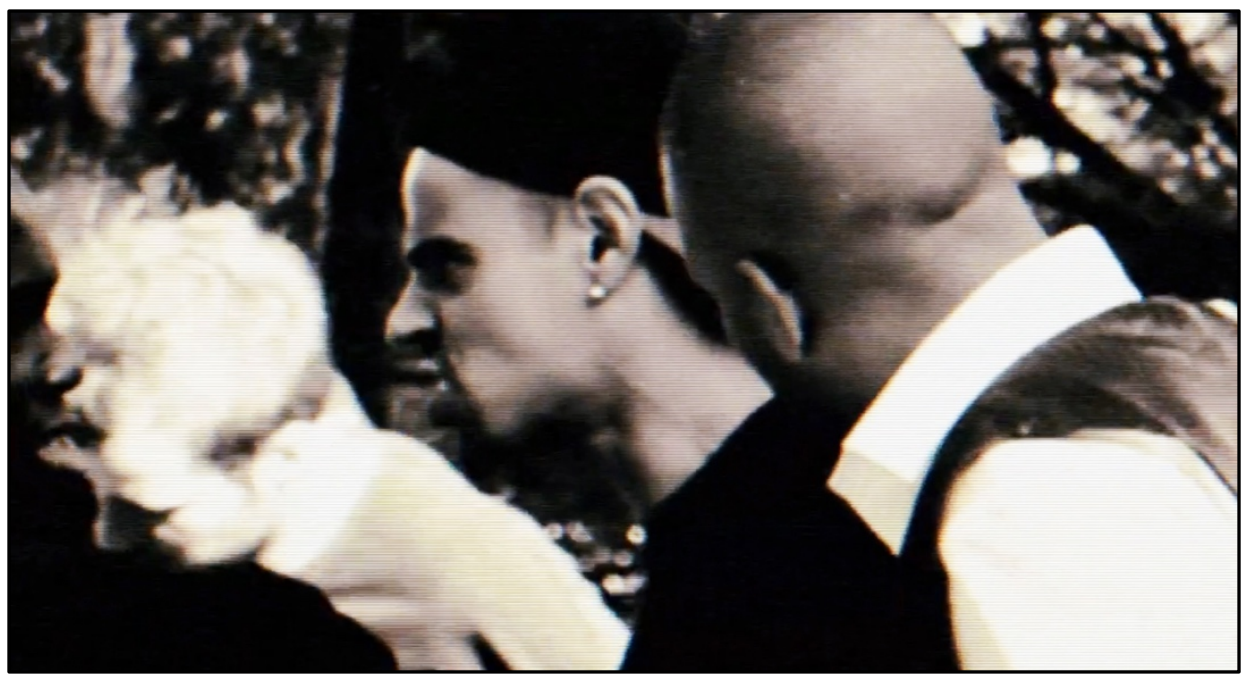

Confrontation between skaters, security guard and local resident in promo video Stella Supply (Henry Edwards-Wood, 2011). https : / /www . youtube.com/watch?v=aer40tuH 4 TC

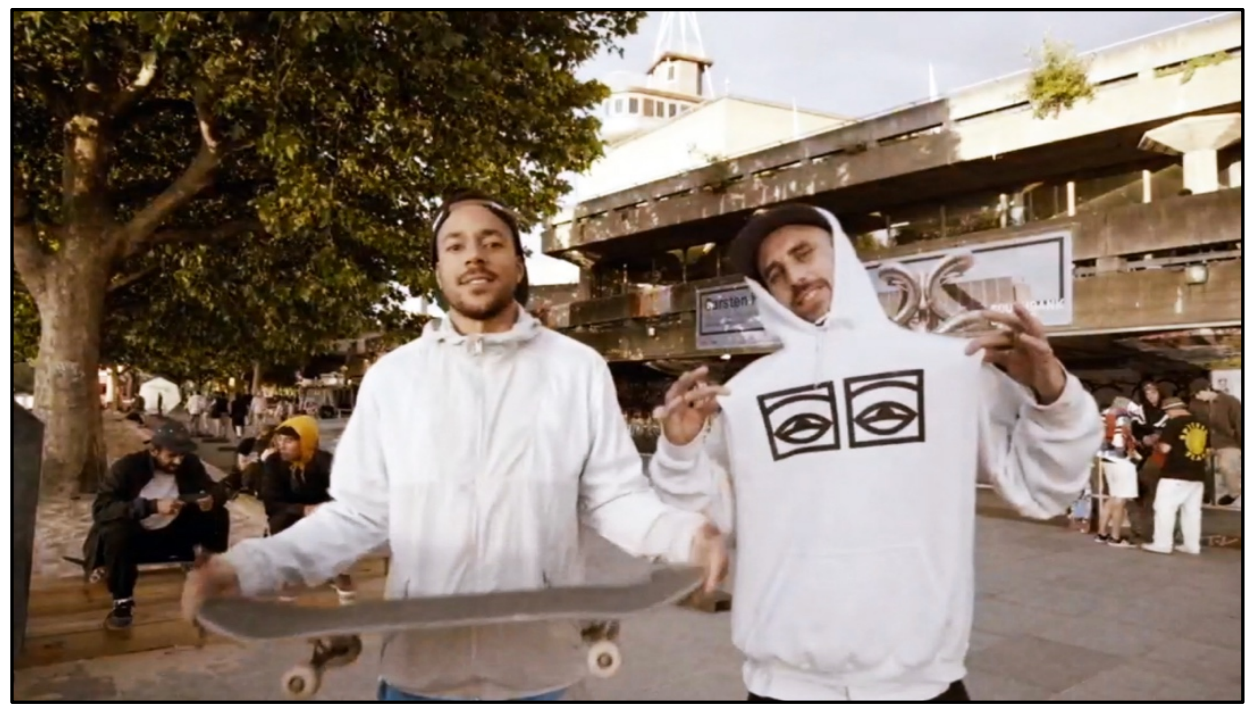

Benny Fairfax (left) and Chewy Cannon (right) in front of the Undercroft, in Adidas' Away Days (Matt Irving, 2016).

https://itunes.apple.com/gb/movie/away-days/id1111275732

As this all shows, some London skateboarding videos now openly operate within a brand-infused global market. Similarly, in 2014 American skate/leisure shoe brand Vans opened House of Vans, a skatepark plus cinema, gallery and gig venue beneath the Waterloo railtracks and close to the Undercroft. As a free-access venture, the House of Vans predominantly pays its way by generating video and social media content for its multibillion dollar owner. For example, the "Crossfire Halloween Massacre" event - a "raucous night" of skate sessions, deathpunks Turbonegro, "Massacre" art and horror films - was aired via a live web feed and innumerable on- 
line videos and blogs. (Leeks) Alternatively, major budget American skateboard videos - such as Krooked's Gnar Gnar (Mark Gonzales and Sam Salganik, 2007), Lakai and Girl's Fully Flared (Spike Jonze, Ty Evans and Cory Weincheque, 2007), Plan B's True (Erik Bragg, 2014) and Vans'

Propeller (Greg Hunt, 2015) - along with independent productions like This Time Tomorrow (Chris Mulhern, 2013) frequently incorporate London within their globe-trotting geography. For example, in Girl and Chocolate's Pretty Sweet (Ty Evans, Spike Jonze and Cory Weincheque, 2012), American professional Sean Malto rides down handrails at Euston Station and London Wall as part of a massive litany of other skatespots, riders and cities worldwide. Similarly in Thrasher Vacation (2014), riders Grant Taylor, Raven Tershy, Ronnie Sandoval and Jack Curtin negotiate skate venues like House of Vans, Stockwell, Rom, Tottenham Hale, Victoria Park, Harrow and the Undercroft, drawing over 275,000 YouTube viewers. London is here being integrated within a well-established form of global skateboard tourism, both real and virtual, part of a worldwide range of similar destinations such as Shanghai and Tokyo, Berlin and Malmo, Philadelphia and Los Angeles, Caracas and Rio - all being used to promote skateboarding culture and markets.

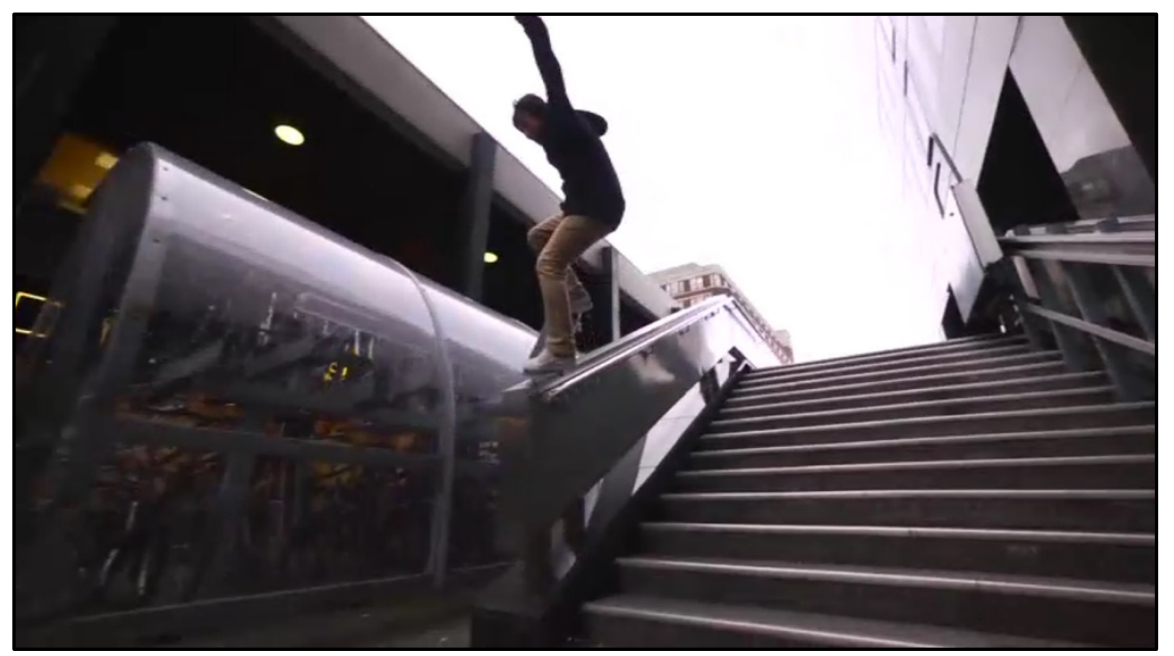

American pro Sean Malto rides a handrail at Euston Station. Pretty Sweet (Ty Evans, Spike Jonze and Cory Weincheque, 2012). https://www.youtube.com/watch?v=aSsSctps9sk

Not all globalised disseminations of London skateboard videos and related social media are, however, so commercially oriented. Ever since skateboarders first devoured 1970s magazines like SkateBoarder and Skateboard! and later became early adopters of camcorder technology, 
photographic and filmic representations have been an integral part of skateboarding. Today, in any given skateboard session at least one group member will typically film proceedings, and then quickly relay recordings via Instagram, Tumblr, WhatsApp, Facebook and/or specialist on-line forums. Alternatively, local groups like South London's With Section will edit together videos like Twenty-Fourteen (2014) and So What? (2016) as rambunctious records of recent adventures, from creating a skatespot in Sydenham in south London to travelling between other DIY skateparks across Europe. Loaded up onto With Section's website, Tumblr and Instagram accounts, these videos are at once self-documentation, local information and global communications, fed via social media into a network of similar productions created by thousands of equivalent skate groups around the world. (wWW.withsection.com)

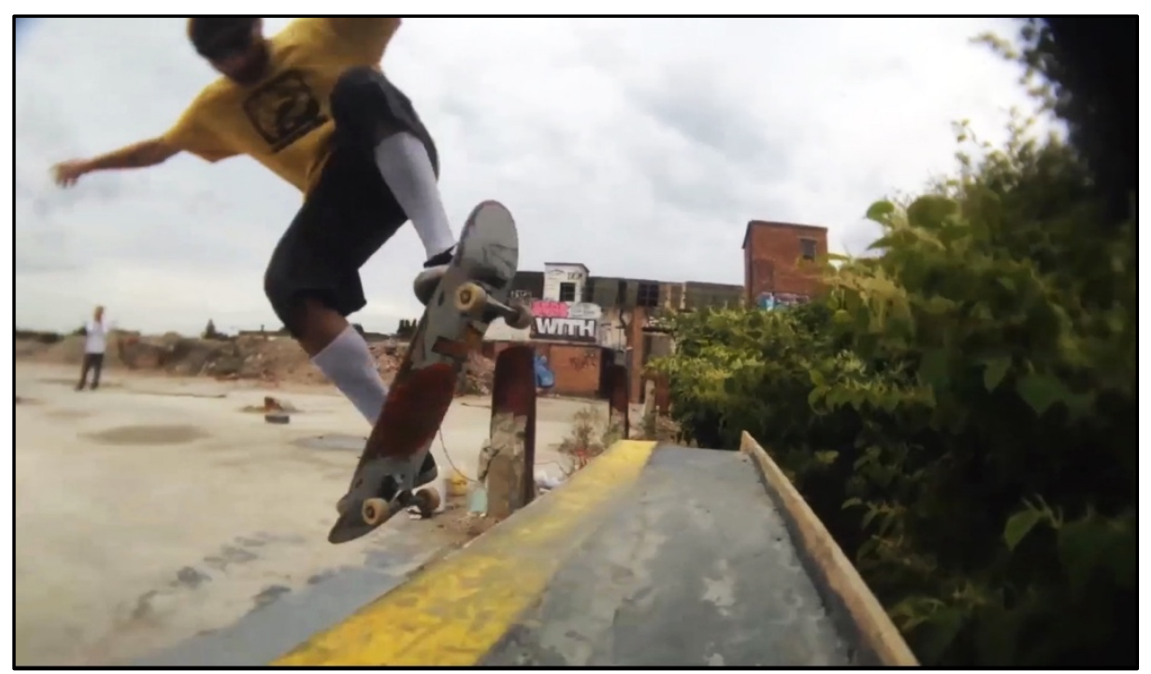

DIY constructed skatespot in Sydenham, south London, by With Section. So What? (2016). https://vimeo.com/168932717

In such manner, films of London skateboarding are constantly being produced and transmitted across global audiences, while side-stepping the various exigencies and constraints of commerce, brands, experts and authorities. This is film as grassroots democratic activity, at once immediate, energetic and connected. Above all, filmic depictions of London skateboarding are now at once recordings of, agents within and communications beyond the immediate confines of the capital. Film is an essential part of how London skateboarders act, enriching both their local lives and wider worlds.

$<$ ENDS $>>$ 


\section{Acknowledgements}

Thanks to Rob Ashby, Andy Beevers, Graham Fletcher-Cook, Rodga Harvey, Peter Jones, Paul Price, Guy Roberts, Michael Stride, Winstan Whitter and the collective knowledge of the Facebook group "Lost \& Found - 1970s Concrete Skateparks in the UK."

\section{References}

"Adidas Originals | Palace Skateboards," 2014.

https: //WwW.youtube.com/watch?v=GI_t7jx2hLI.

"Adidas Skateboarding Benny \& Chewy Palace," 2014. http: //wWw . youtube.com/watch?v=LMlDUC6t6fM.

“Baker Skates." http://www.youtube.com/watch?v=ZNQ6NTSsRQ8.

"BBC London News Features Skateboarding for Adults in London," (October 31 , 2014 ). http: //www . youtube.com/watch?v=QBTWMtiYnrQ.

BBC1 News, October 29, 2014 .

“Benjyboard promo video." http://www.youtube.com/watch?v=kQMBO-Nsyy4

Iain Borden, Skateboarding, space and the City (Oxford: Berg, 2001), revised as Skateboarding and the City (London: Bloomsbury, 2018 /forthcoming).

Iain Borden, "Southbank Skateboarding, London and Urban Culture," in Skateboarding, ed. Kara-Jane Lombard (Abingdon: Routledge, 2015), 91-107.

Iain Borden, "Things that People Cannot Anticipate," in Forty Ways to Think About Architecture, ed. Iain Borden, Murray Fraser and Barbara Penner, (Chichester: Wiley, 2014), 100-05.

John Boykin and Bob Grant, "Skateboard Acrobatics," Popular Mechanics, July, $1965,81-5$.

François Brown de Colstoun, "Skate City, London," Skate, 2, Mars-Avril, $1978,23-5$.

Sean Dinces, "Flexible Opposition," International Journal of the History of Sport 28/11 (2011), 1512-35.

Catherine Elwes, Video Art (London: IB Tauris, 2005), 5.

Hunter Fine, “The Skateboard Dérive," Liminalities 9/3 (2013), 1-20.

"Gremlins and Sandies in New Craze," (British Pathé, 1964). http: //www . youtube.com/watch?v=g 4 qXZ5 XMDwA.

Sam Griffin, "Skateboarding in the Age of Mechanical Image Reproduction: From Powell Peralta to T-Puds," lecture text, 2010.

"Hold Tight London." http://www.vimeo.com/user1544299.

"HRH The Prince of Wales visit to Inter-Action," (1978). http: //www.vimeo.com/27787836. 
ITN, "Rom Skatepark in Romford Receives Listed Status," story ref T29101409. http: //Www.itnsource.com.

“Jeremy Henderson 02.avi." http://www.youtube.com/watch?v=mIqqJQoHypo.

"John Sablosky.avi". http://www.youtube.com/watch?v=cfNvja_u-RI.

"Jules Gayton.avi." http://www.youtube.com/watch?v=dfS618H50xM.

Zac Leeks, “Vans X Crossfire Halloween Massacre 2014," Crossfire, October 7, 2014. http://WwW.caughtinthecrossfire.com.

Ben Liddell, post in Facebook group "Lost \& Found - 1970s Concrete Skateparks in the UK," June 15, 2016.

"Lip Torque," Skateboard!, 6, February, 1978, 32-3.

Kara-Jane Lombard, "Trucks, Tricks, and Technologies of Government," in Skateboarding, ed. Kara-Jane Lombard (Abingdon: Routledge, 2015), 169-81.

London Night Skate (dir. Tim Kellner, 2014).

http: //www . youtube.com/watch?v=AL08KozYkT8.

“Major Moves," Thrasher, 11/9, September, 1991, 48.

"Marc Sinclair.avi." http://www.youtube.com/watch?v=s0AWeRz0hwc.

Ben Marcus and Lucia Daniella Griggi, The Skateboard (Minneapolis: MVP Books, 2011 ).

"Matt Hensley on Skateboarding and Joining Flogging Molly," RIDE Channel, May 18, 2012. http://www.youtube.com/watch?v=RU0gz410Kp4.

"National Skateboard Show, Royal Horticultural Hall, London (12-15 Feb 1978 )." https://www.youtube.com/watch?v=heaTU_-s59I.

Nick Jensen on His Painting and Skating (dir. Phil Evans, 2010). http: //www. youtube.com/watch?v=2oa1XMglupg.

Over Plywood (dir. Jono Atkinson, 2015).

Passenger (dir. Angus Leadley Brown, 2004). http://www.vimeo.com/103470163

Hazel Pennell, Skateboarding (London: GLC Intelligence Unit, London Topics n. 24,1978$)$.

Jim Phillips, Surf, Skate \& Rock Art of Jim Phillips (Atglen: Schiffer, 2004 ).

Jim Phillips, The Skateboard Art of Jim Phillips (Atglen: Schiffer, 2007).

"RAD - a Look at London's Skateparks."

http: //www $\cdot$ youtube.com/watch?v=8K_roobnvru.

“RAD - London's Skate Spots," http://www.youtube.com/watch?v=6pn_t6s-1TE.

"Reports on the 1st National Championships," Skateboard Special, 1, September, 1977), 10-11.

Rollin' through the Decades (dir. Winstan Whitter, 2005).

"Skateboarding Around the World," The Quarterly SkateBoarder, 1/2, Spring, $1965,38-9$. 
"Skate Boarding: Skate City," September 25, 1977, story ref FS0210131984. http: //www.itnsource.com

"Skateboard Mania," Life, May 14, 1965, front cover and 126-32.

"Skate City." http://www.vimeo.com/58460999.

Skate Park Construction, advertisement, Skateboard!, 4, December, $1977,51$.

Craig B. Snyder, A Secret History of the Ollie (Delray Beach: Black Salt Press, 2015).

"So What Full Vid," 2016. http://Www.vimeo.com/168932717.

Quentin Stevens and Kim Dovey, "Appropriating the Spectacle," Journal of Urban Design, v.9 n.3 (2004), 351-65.

"The Man Who Spotted the Skateboard Trend," Skateboard Special, 1, September, 1977,8 .

The Panoramic Series - London with Nick Jensen (dir. Philip Evans, 2013). http: //www.vimeo.com/67379316.

“The Sun Rises on Skate City," Skateboard!, 2, October, 1977, 28-30.

The Sun, "The Sun British Skateboard Championships," Skateboard!, 10, June, $1978), 85$.

"Team of Youngsters Try Out Europe's Largest Skateboard Park," May 1978, story ref BGY510280114. http://WWW.itnsource.com.

Thrasher Vacation. "Thrasher Vacation: England," 2014.

http: / /wWw . youtube.com/watch?v=nu0IQkNsWmc.

"Tory Leader, Mr Heath Off Duty," (ITN, 13 March 1966).

http: //www.itnsource.com.

“UK News," Skateboard!, 3, November, 1977, 8.

"United States Skateboarding Aces on UK Visit to Demonstrate Their Perilous Art," October 18, 1977, story ref BGY510210293. http://www.itnsource.com.

"Vintage Footage of Rolling Thunder Skatepark." http: //www $\cdot$ youtube.com/watch? $v=t p 5 \times 3$ fCcnE.

With Section, http://www.withsection.com. Accessed August 2, 2016.

"Young Skateboard Fans Demonstrate Their Skills at Opening of Europe's

First Covered Skatepark," March 7, 1978, story ref BGY510260107.

http: //www.itnsource.com. 